\title{
Immune and inflammatory responses in pigs infected with Trichuris suis and Oesophagostomum dentatum
}

Andreasen, Annette; Petersen, Heidi Huus; Kringel, Helene; Iburg, Tine M.; Skovgaard, Kerstin; Dawson, Harry; Urban Jr., Joseph F.; Thamsborg, Stig M.

Published in:

Veterinary Parasitology

Link to article, DOI:

10.1016/j.vetpar.2014.12.005

Publication date:

2015

Document Version

Early version, also known as pre-print

Link back to DTU Orbit

Citation $(A P A)$ :

Andreasen, A., Petersen, H. H., Kringel, H., Iburg, T. M., Skovgaard, K., Dawson, H., Urban Jr., J. F., \& Thamsborg, S. M. (2015). Immune and inflammatory responses in pigs infected with Trichuris suis and Oesophagostomum dentatum. Veterinary Parasitology, 207(3-4), 249-258.

https://doi.org/10.1016/j.vetpar.2014.12.005

\section{General rights}

Copyright and moral rights for the publications made accessible in the public portal are retained by the authors and/or other copyright owners and it is a condition of accessing publications that users recognise and abide by the legal requirements associated with these rights.

- Users may download and print one copy of any publication from the public portal for the purpose of private study or research.

- You may not further distribute the material or use it for any profit-making activity or commercial gain

- You may freely distribute the URL identifying the publication in the public portal 


\section{Immune and inflammatory responses in pigs infected with Trichuris suis}

and Oesophagostomum dentatum

Annette Andreasen ${ }^{\mathrm{a},{ }^{*}}$, Heidi H. Petersen ${ }^{\mathrm{a}}$, Helene Kringel ${ }^{\mathrm{a}}$, Tine M. Iburg ${ }^{\mathrm{b}}$, Kerstin Skovgaard ${ }^{\mathrm{c}}$, Harry Dawson ${ }^{\text {d }}$, Joseph F. Urban Jr. ${ }^{\text {d }}$, Stig M. Thamsborg ${ }^{\text {a }}$

${ }^{a}$ Parasitology and Aquatic Diseases, Department of Veterinary Disease Biology, Faculty of Health and Medical Sciences, University of Copenhagen, Dyrlcegevej 100, DK-1870 Frederiksberg C, Denmark.

${ }^{b}$ Department of Pathology and Wildlife Diseases, National Veterinary Institute, SE-751 89 Uppsala, Sweden.

${ }^{c}$ Innate Immunology Group, National Veterinary Institute, Technical University of Denmark, 1870 Frederiksberg C, Denmark.

${ }^{d}$ USDA, ARS, Beltsville Human Nutrition Research Center, Diet, Genomics, and Immunology Laboratory, Beltsville, MD 20705, USA.

*Corresponding author. Address: Annette Andreasen, Parasitology and Aquatic Diseases, Department of Veterinary Disease Biology, Faculty of Health and Medical Sciences, University of Copenhagen, Dyrlægevej 100 building 1-05 3., DK-1870 Frederiksberg C, Denmark.

Tel.: +45 208759 18; fax: +45 35332774

E-mail address: malte@sund.ku.dk (A. Andreasen) 